ReVISTA de BIOLOGía TROPICAL

\title{
Breeding biology and hatching success of Chelonia mydas (Testudines: Cheloniidae) in Aves Island Wildlife Refuge, Venezuela, during the 2010 reproductive season
}

\author{
David A. Prieto-Torres ${ }^{1,2}$ \& Jim Hernández-Rangel ${ }^{1}$ \\ 1. Laboratorio de Investigaciones Piscícolas "Dr. Lino J. Hernández”, Facultad Experimental de Ciencias. Universidad \\ del Zulia. Avenida 59 (Universidad) con calle 77, Sector Grano de Oro, Maracaibo, Venezuela; jimlenran@gmail.com \\ 2. Eje BioCiencias, Centro de Modelado Científico (CMC) de la Universidad del Zulia. Avenida 59 (Universidad) con \\ calle 77, Sector Grano de Oro, Maracaibo, Venezuela; dprieto@cmc.org.ve
}

Received 02-II-2015. Corrected 12-V-2015. Accepted 11-VI-2015.

\begin{abstract}
Aves Island Wildlife Refuge is the second most important nesting colony for green turtles (Chelonia mydas) in the Caribbean. Even though some research projects have led to a solid source of knowledge about this species' ecology, little information about its breeding biology is available. This study was focused on assessing the breeding characteristics and hatching success for the nesting population during the 2010 season in Aves Island, Venezuela. Nesting data were collected along the entire beach line from July $31^{\text {st }}$ to November $09^{\text {th }}$ by nightly patrols, in order to determine green turtle nesting activity. All females were tagged and measured to compare the new recruits with remigrant females. We determined the number of nesting females, the size and spatial distribution of clutches, the incubation period, the internesting and remigration periods, as well as the hatching and emergence success for first time in Aves Island. Beach dimensions were measured to determine nest density. We recorded 1106 nesting females with 436 remigrant females individually identified. The female population had an average curved carapace length of $112.2 \pm 5.5 \mathrm{~cm}$. The average clutch size was of $124 \pm 25.7$ eggs, with an estimated clutch frequency of 2 nests/females, and an average inferred clutch period of 12.4 days. We estimated the total number of clutches to be $2261 \pm 33$ and a total of $1130 \pm 17$ nesting females for the 2010 season. For in situ nests, we observed a Mean hatching and emergence success of $54.4 \pm 30.0 \%$ and $74.3 \pm$ $29.2 \%$, respectively. There was a positive correlation between the morphometrics of nesting females and clutch size, and also significant differences in the number of clutches and hatching and emergence success among the different island sections of the study site. Our results are only a first attempt at characterizing this site population, but have great value for establishing conservation priorities within the context of national management plans. Care should be taken in extrapolating our data to other years, as there is a need to continue monitoring the nesting beach and developing conservation strategies directed at all life-stages of the population. Rev. Biol. Trop. 63 (4): 1059-1070. Epub 2015 December 01.
\end{abstract}

Key words: Aves Island, Chelonia mydas, hatching success, nesting population, reproductive success.

The Green Turtle (Chelonia mydas) is one of five sea turtle species in Venezuela, distributed along several areas of the continental coast (about $2000 \mathrm{~km}$ long) and its system of islands, including Aves Island. This large expanse provides a wide range of habitats for the development, feeding, breeding, refuge, and nesting of this species (Guada \& Solé, 2000). Aves
Island Wildlife Refuge (Refugio de Fauna Silvestre Isla de Aves in Spanish, or RFSIA) is considered a reference site and indexed for the global population of green turtles (Seminoff, 2004; Vera \& Buitrago, 2012), as it is the main nesting site in Venezuela, and the second most important nesting colony in the Caribbean, with a total of 300 to 600 nesting 
females between July and September (Pritchard \& Trebbau, 1984; Guada \& Solé, 2000; Guada \& Buitrago, 2008).

The monitoring and tagging of sea turtles in RFSIA was started by the "Island Resources Foundation" and "Fundación La Salle de Ciencias Naturales" (Rainey \& Pritchard, 1972; Rainey, 1977). In 1978 the scientific-naval base "Simón Bolivar" (Base Científico Naval Simón Bolivar in Spanish, or BCNASBO) was installed to protect the Wildlife Refuge by presence of military personnel. Since 1979 to 1997, the "Fundación para la Defensa de la Naturaleza" (FUDENA) systematically developed the monitoring efforts. However, the activities were interrupted from 1998-2000 until 2001, when the Venezuelan Ministry of Environment (Minamb, in Spanish) re-initiated tracking activities with the project "Seguimiento y Conservación de la población de tortuga verde en el Refugio de Fauna Silvestre Isla de Aves", with a data collection effort to assess the reproductive success and health of the nesting population during the first 10 years of study (Prieto-Torres et al., 2012; Vera \& Buitrago, 2012; Prieto-Torres, Hernández, Bravo, Alvarado, \& Dávila, 2013; Prieto-Torres \& Hernández, 2014).

Currently, RFSIA has the second oldest conservation program for green turtles in the Caribbean and has generated over two decades of biological information on this species. The evident increase in the number of nesting females per season documented previously in RFSIA during the 1979-1997 (Peñaloza, 2000) and 2001-2008 seasons (Vera \& Buitrago, 2012) is a promising sign of population recovery and shows the importance impact that 30 years of protection has had on the number and females' growth (Vera \& Buitrago, 2012).

However, the estimates of female number in species with as complex reproductive cycle -as sea turtles- have uncertainties very large in sites logistically difficult to access as the RFSIA. Therefore, efforts should be supported with resources appropriate to obtain data in the short, medium, and long-term in order to assess the reproductive success of population.
To understand the success of reproductive effort in sea turtles species, which have late maturity, it is necessary to know the clutch frequency and number of eggs laid (as well as their diameter and weight) per female; as well as to the incubation periods of nests and the number of hatchlings that hatch successfully, emerge from the nests, and reach the sea successfully per season (Miller, 1997; 1999). A significant change (based on the Mean and standard deviation of the study population) in the values for these reproductive parameters in a population over time indicates that problems may be occurring, and that the implementation of actions for the conservation and management of the population is needed (Miller, 1999). However, Peñaloza (2000) did not provide any quantitative data of hatchlings during her demographic study on RFSIA populations, and Vera and Buitrago (2012) determined only the clutch frequency and the number of nesting female green turtles in RFSIA during 20012008. Therefore, to date the values of many nesting characteristics, such as hatchling success, for this population remain unknown.

To address this need, the objective of this study was to characterize the reproductive parameters for the nesting population, including the hatching and emergence success for first time, of green turtles in RFSIA during the 2010 season. All results were compared with data from previous seasons in RFSIA and other principal nesting colonies in the Caribbean. The short-term records of these parameters can help to characterize the reproductive biology of the green turtle population in RFSIA, define conservation priorities for populations, as well as determine the importance of the studied beach for the survival of this species in the Caribbean and Atlantic. In addition, we have included some comments on conservation efforts and policy decisions that have influenced the nesting trend since 1979s.

\section{MATERIALS AND METHODS}

Study site: Aves Island (15 $40^{\prime} \mathrm{N}-63^{\circ} 37^{\prime}$ $\mathrm{W})$ is a Federal entity located in the Caribbean 
Sea, approximately $580 \mathrm{~m}$ long and $140 \mathrm{~m}$ wide (30 $\mathrm{m}$ at its narrowest point) with a total area of $36000 \mathrm{~m}^{2}$ and elevation of no greater than 3.5 m. It was declared a Wildlife Refuge in 1972 by Decree No. 1069 in the Official Gazette No. 29888 (Vera, 2004).

To facilitate the data collection and to document with more precision the spatial distribution of nests, the beach was divided into three sections, from South to North considered the position of BCNASBO: Section $\mathrm{A}=$ $12300 \mathrm{~m}^{2}$; section $\mathrm{B}=8700 \mathrm{~m}^{2}$, and section $\mathrm{C}=15000 \mathrm{~m}^{2}$ (Gremone \& Gómez, 1983). We recorded the coordinates of each nest or group of nests in high density areas with a global positioning system using a Garmin ${ }^{\text {tm }}$ GPS and mapped them using ArcMap ver. 9.3 software.

Data collection: Nesting data were collected along the entire beach line from July $31^{\text {st }}$ to November $09^{\text {th }} 2010$ by nightly patrols that started at 20:00pm and ended at 04:00am, following the standard methods for sea turtle research (Eckert, Bjorndal, Abreu-Grobois, \& Donnelly, 2000). The selection of the study period was due to logistical difficulties in accessing the Wildlife Refuge; transportation is only provided by the Venezuelan Navy every two months. Although Chelonia mydas can nest throughout the year (from February to November), the study period used in our work represents the peak of the reproductive season and more than $80 \%$ of nesting activity in a year (Vera \& Buitrago, 2012), allowing us to obtain information that would provide an estimate of population trends and allows for the detection of important biological changes within the population given the nesting activity of this species (Sims, Bjorkland, Mason, \& Crowder, 2008; Vera \& Buitrago, 2012).

All females were checked for old tags or tag scars, which indicates a remigrant female. Untagged females were marked in the front flippers with Inconel metal tags $\mathrm{N}^{\circ}$ 681 (National Band \& Tag Company, Newport, KY, USA) during the oviposition process or covering processes (Ferrer, Díaz, \& Díaz, 2007; Piedra, Vélez, Dutton, Possardt,
\& Padilla, 2007). Morphometric data were collected using a flexible measuring tape of $1.5 \mathrm{~m}$ in length. We measured the curved carapace length (CCL) and curved carapace width (CCW; Bolten, 1999).

Tagging the females allowed for the estimate of reproductive parameters, such as average observed clutch frequency (OCF) and average internesting interval. We defined OCF as the number of ovipositions observed during the season for an individual (Alvarado \& Murphy, 2000; Sarti et al., 2007). Observed internesting period (OIP) was defined as the number of days between a successful nesting and the first attempt at a subsequent nesting per female (Ferrer et al., 2007). These calculations excluded intervals of less than $7 \mathrm{~d}$, as well as aborted nesting attempts, based on Miller (1997), who determined a minimum internesting period of $6 \mathrm{~d}$. The remigration period (number of years between two sequential nesting seasons) was determined using as reference the documentation of the last nesting event for each female, included in the database of Minamb's conservation project (Vera, 2004).

The management of the clutches was carried out in two ways: (1) if the turtle was observed before oviposition and the area was considered suitable for nesting, eggs were left in situ and counted directly during the process; and (2) if the place chosen by the turtle was extremely risky for the nest (being very close to sea level) the eggs were collected in clean plastic bags and relocated to the Northern section of the beach, always within the first $6 \mathrm{~h}$ of oviposition (Miller, 1997). We relocated only 36 nests during this study. To determine clutches size in both cases, we employed a manual count and only counted normal eggs (Rees, Saad, \& Jony, 2005).

Incubation period was calculated as number of days between oviposition and emergence of the first hatchlings (Godfrey \& Mrosovsky, 1997). The nests were excavated and examined for hatching success from three to five days after emergence. We classified their contents and recorded the number of live and dead hatchlings that remained in the nest, the 
number of empty shells, unhatched eggs with and without embryos, predated eggs, and undeveloped eggs. We determined hatching success and emergence success for 71 nests according to the criteria proposed by Miller (1999). Hatching success was defined as the number of hatched eggs divided by the total number of eggs, while emergence success was defined as the number of hatched eggs minus the number of hatchlings remaining in the nest divided by the total number of eggs.

Estimation of nesting females and number of clutches: Most studies in nesting beaches present uncertainties on times and areas covered between seasons. Therefore, to estimate the number of nesting females in RFSIA, the methods are based on the estimated clutch frequency (ECF) and Mean estimated internesting period (EIP) for all females, which were inferred from the observed events during the sample periods (Alvarado \& Murphy, 1999; Gerrodette \& Taylor, 1999; Broderick, Glen, Godley, \& Hays, 2002; Vera \& Buitrago, 2012). To calculate the inferred internesting interval, we considered that one or more intermediate nests were not reported when the span between two consecutive nesting sites was much higher than the range normally observed (Alvarado \& Murphy, 1999). The ECF was calculated based on these inferences (Broderick, Glen, Godley, \& Hays, 2003).

To estimate the missing events for all seasons we used the adjusted distribution of the proportion of nesting events per year in RFSIA, estimated by Vera and Buitrago (2012). We estimated the number of clutches per season by calculating the nesting success (p) for the events observed during the study period; this parameter is defined as how many of these events produced a spawning (Huerta, 1998; Vera \& Buitrago, 2012). To estimate the number of nesting females we used corrected data (unobserved events and nesting success) following the Gerrodette and Taylor (1999) criteria, which is equivalent to the number of estimated clutches/estimated clutch frequency.
Statistical analyses were conducted using SPSS (version 19.0) for Windows. To evaluate the normality of data we used the ShapiroWilk statistic. We used a $t$-student test to determine differences for morphometric values between females tagged in previous seasons (considered remigrant females) and females tagged in 2010 (considered new recruits). A $t$-student test was performed to evaluate differences for OCF between new recruits and gravid females. We used the Kruskal-Wallis test to identify differences in clutch size and internesting periods among nesting females by remigration periods (two, three, and more than three years). To determine if the females preferred the section A, B or C of the beach we performed a Chi-Squared test with the expected values calculated in relation to the surface area of each section. Additionally, we used the Kruskal-Wallis test to evaluate differences in incubation periods and hatching and emergence success of clutch among the island sections. Finally, Spearman correlations were performed to determine relationships between the CCL and $\mathrm{CCW}$ of nesting females with regards to clutch size, clutch frequency, and hatching success, as well as with the incubation period, clutch size, hatching success, and the number of undeveloped eggs in the nests. All values are presented as Mean $\pm \mathrm{SD}$, and all $p$ values are significant at alpha $=0.05$.

\section{RESULTS}

Tagging program and nesting biology: A total of 1106 nesting green turtles were recorded during the $102 \mathrm{~d}$ that we conducted surveys in RFSIA: 670 (59.6\%) were tagged during this season and 436 (40.4\%) females were individually identified as remigrants, while three females (FWI 3088, FWI 4638/4639, and FWI 5406) were tagged in Guadalupe National Park, Guadalupe Island in the Lesser Antilles. We obtained an average of $2.5 \pm 1.01$ years for the remigration period with predominant intervals of $2(57.8$ $\%), 3(12.4 \%)$, and $4(7.8 \%)$ years. The two older females found during this season had been tagged for over 20 years, one individual in 1984 
(B 4961) and the other in 1988 (RRB 749/YYK 837). The green turtle females had a Mean of $112.2 \mathrm{~cm}(\mathrm{SD}=5.5)$ for $\mathrm{CCL}$ and of $101.9 \mathrm{~cm}$ $(\mathrm{SD}=5.3)$ for $\mathrm{CCW}$. We found significant differences for morphometric values between more recently tagged females (smaller and considered new recruits) and previously tagged females (remigrant females) (LCC: $t=6.48$, ACC: $t=$ 4.95; $\mathrm{df}=1080, \mathrm{P}<0.001)$.

A total of 488 females nested throughout the season (1-6 nests). The OIP was $19.5 \mathrm{~d}$, without significant differences between the observed intervals of remigration periods for females (Kruskal-Wallis test: $\mathrm{H}=2.49, \mathrm{P}>$ 0.05). We documented an EIP of $12.4 \mathrm{~d}$. This population had an average OCF of 1.6 and ECF of 2.0 nests/female with no correlation between the CCL and OCF females $(\mathrm{r}=0.07, \mathrm{P}=0.02$, $\mathrm{N}=960$ ). There were no significant differences in the OCF between new recruits and gravid females $(t=-0.02 ; \mathrm{df}=966, \mathrm{P}=0.98)$.

Estimated number of clutches and nesting females: For a sample of 2029 events observed during data collection, the nesting success rate was $74.5 \%(\mathrm{SD}=0.02)$. We used information on the proportion of successful nesting events calculated by Vera and Buitrago (2012) and estimated $3036(\mathrm{SD}=44)$ nesting events with $2261(\mathrm{SD}=33)$ successful nests and a total of $1130(\mathrm{SD}=17)$ nesting green turtle females for the 2010 season (Fig. 1).

Spatial distribution, clutches, incubation, hatching, and emergence success: During the study period, we observed a total of 1511 nests of green turtles, with the highest number of nests $(\mathrm{N}=679)$ observed in the beginning of the month of September. The peak-nesting season was during the period from August 27 to September 23, with $62.7 \%$ (948 traces) of total activity and $45.0 \%$ (680) of clutches observed this period. In general, nesting processes were observed over the entire surface of the island (Fig. 2). We counted 565 clutches $(37.4 \%)$ in section A, 310 clutches (20.5\%) in section B, and $636(42.1 \%)$ in section $C$, with significant differences among expected number nest in relation to the surface of every section beach $\left(X^{2}=13.08, \mathrm{df}=2,0.001\right)$.

The average clutch size was 124 eggs (SD $=25.7, \mathrm{~N}=173$ ), with a positive correlation

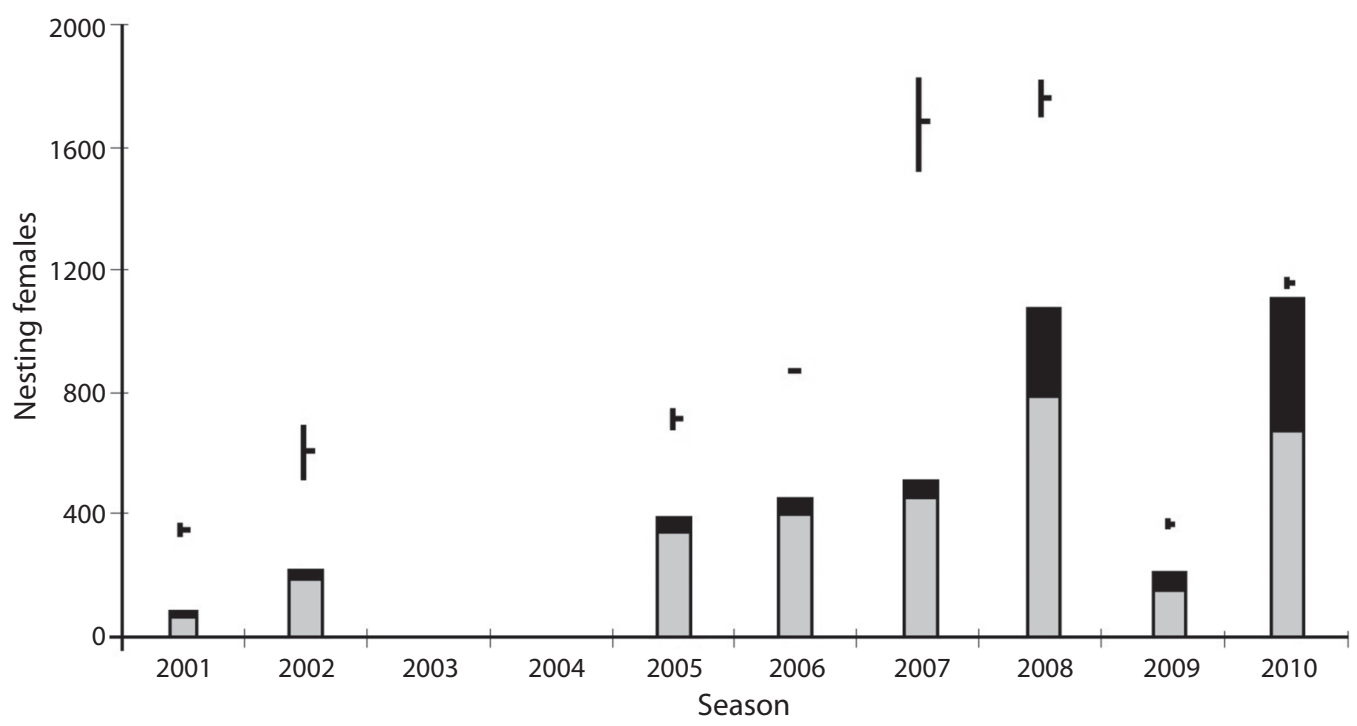

Fig. 1. Number of nesting females observed and estimated per season (from 2001 to 2010) on Aves Island Wildlife. Bars represent the observed number of females tagged (gray) and remigrants (black). Black line represents the variation (Mean and SD) in the estimated number of nesting females. Modified from Vera and Buitrago (2012). 
between the size of the nesting female and the number of eggs per clutch (CCL: $r=0.34$; ACC: $\mathrm{r}=0.277 ; \mathrm{P}<0.01, \mathrm{~N}=129)$ but without significant differences between females (new recruits $v s$. gravid females) in the clutch size $(\mathrm{H}=5.98, \mathrm{P}>0.05)$. The in situ nests ranged in incubation period from 43 to 78 (Mean $=58$, $\mathrm{SD}=8$ ) days without any correlation between the incubation period and the number eggs in the nest $(\mathrm{r}=-0.116, \mathrm{P}>0.05, \mathrm{~N}=41)$ or between the incubation period and the position of the nests on the island: sections $\mathrm{A}, \mathrm{B}$, and $\mathrm{C}$ $(\mathrm{H}=2.23, \mathrm{P}=0.32, \mathrm{~N}=41)$.

A total of 78 in situ nests (including some nests with high probability of loss due to flooding) were checked: 41 previously tagged and monitored daily and 37 reviewed postemergency (Rees et al., 2005); for a total of 10222 eggs counted. The hatching success obtained for these clutches was $54.4 \%$ (SD $=30.0$ ), with an emergence success of $74.3 \%$ $(\mathrm{SD}=29.0)$ where a total of 4799 hatchlings emerged alive. Table 1 shows the number of nests, Mean clutch size, incubation period, and hatching and emergence success by island sections for the in situ nests evaluated. We found significant differences for the hatching $(\mathrm{H}=$ 9.97, $\mathrm{df}=2, \mathrm{P}<0.05, \mathrm{~N}=78)$ and emergence success $(\mathrm{H}=7.59, \mathrm{df}=2, \mathrm{P}<0.05, \mathrm{~N}=78)$ between island sections, with higher percentages obtained in the Northern section (64.6 and $83.1 \%$, respectively).

We counted a total of 833 dead offspring at hatching, 90 alive embryos, 1670 dead embryos, and 2830 undeveloped eggs during the review of nests in situ. No correlation was found between the number of eggs in the nest and the number of undeveloped eggs in clutches

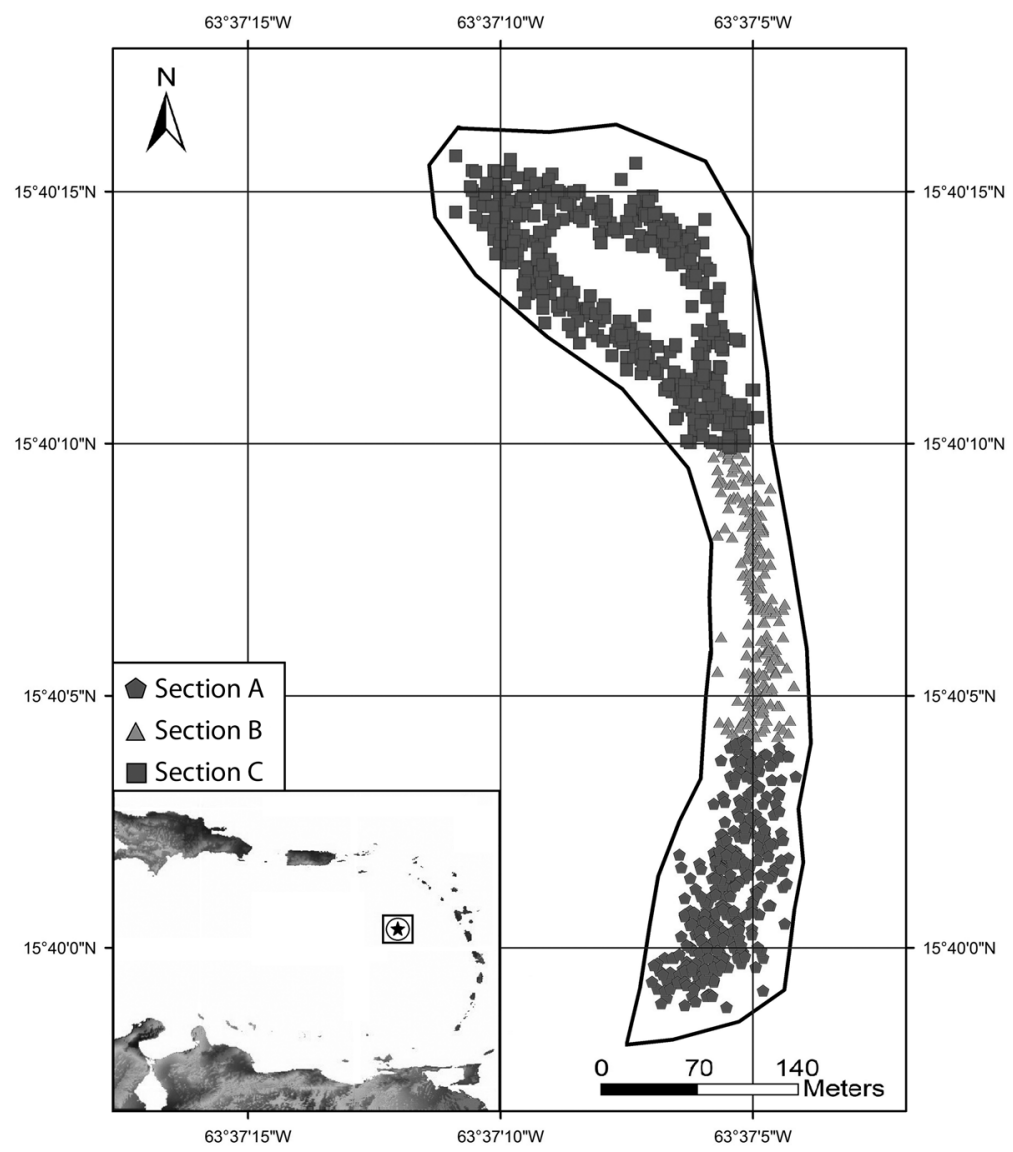

Fig. 2. Spatial distribution of nests at Aves Island in the A, B, and $\mathrm{C}$ sections: each symbol represents a single nest. 
TABLE 1

Reproductive statistics for nesting females of Chelonia mydas by sections in Aves Island: 2010 Season

\begin{tabular}{lcccccc} 
Sections & $\begin{array}{c}\text { Surface } \\
\left(\mathrm{m}^{2}\right)\end{array}$ & Nest count & $\begin{array}{c}\text { Size of } \\
\text { clutches (eggs) }\end{array}$ & $\begin{array}{c}\text { Incubation } \\
\text { Periods (days) }\end{array}$ & $\begin{array}{c}\text { Hatchling } \\
\text { Success (\%) }\end{array}$ & $\begin{array}{c}\text { Emergence } \\
\text { Success (\%) }\end{array}$ \\
South & 12300 & 565 & $119.1 \pm 22.0$ & $60 \pm 9$ & $39.1 \pm 31.9$ & $65.4 \pm 35.5$ \\
Central & 8700 & 310 & $129.9 \pm 19.7$ & $58 \pm 5$ & $43.7 \pm 33.6$ & $58.7 \pm 37.5$ \\
North & 15000 & 636 & $124.5 \pm 25.0$ & $56 \pm 8$ & $64.6 \pm 24.6$ & $83.1 \pm 19.6$ \\
& Means & & $124.0 \pm 25.7$ & $58 \pm 8$ & $54.4 \pm 30.0$ & $74.3 \pm 29.2$ \\
\hline
\end{tabular}

in situ $(\mathrm{r}=0.12, \mathrm{P}>0.05, \mathrm{~N}=78)$. Additionally, for the 36 nests (4465 eggs) relocated to the North section there was a hatching success of $0.0 \%$, with a total of 24 dead offspring at hatching, 422 dead embryos, 3975 (89.1\%) undeveloped eggs, and 41 indeterminate eggs.

\section{DISCUSSION}

The long-term tag-recapture program and the use of technologies for identifying individuals gave us a better understanding of the situation of the green turtle population in Venezuela and of the dynamics of nesting processes in RFSIA. The increase observed in numbers of tagged females per season in the last 10 years is a direct reflection of the increase in sampling effort, the participation of trained personnel, and the use of systematic methods during the study periods by the Venezuelan Ministry of Environment (Vera \& Buitrago, 2012). Only for the 2003 and 2004 periods there is no information, due to the remodeling of BCNASBO. For the 2009 season, data was collected for only 21 days due the logistical problem of moving personnel in the field, which was reflected in the low number of recorded nesting females.

The morphometric data for nesting females in RFSIA was similar to data documented by Gremone and Gómez (1983) during the 19791983 periods and by Vera (2004) during the 2001-2002 periods. This population was larger on average than Tortuguero $(\mathrm{LCC}=105.4$ $\mathrm{cm})$, Plataforma Suroeste and Guanahacabibes Peninsula, Cuba $(\mathrm{LCC}=100.0-110.00 \mathrm{~cm}$; Nodarse, Moncada, Meneses, \& Rodríguez, 2000; Atkinson, Nolasco, \& Harrison, 2011;
Aranza et al., 2013). However, size is not always an indicator of age, and it would not be possible to conclude that average nesting females in this population are older than these Atlantic populations. Yet, the high percentage of untagged females (apparent neophytes, unless they nested before on a beach with no tagging program) probably indicated new firsttime nesters that had just matured and were nesting for the first time (Piedra et al., 2007; Sarti et al., 2007; Aranza et al., 2013). The proportion of tagged females seen on the RFSIA indexed beaches during the 2010 season was similar to the one reported $(72.8 \%)$ for Tortuguero, Costa Rica, for same season (Atkinson et al., 2011). Thus, there is an important and constant recruitment to this population each year, which is probably due to habitat protection during the years that preceded this study in RFSIA.

The values obtained for OIP in this season were higher than those reported in principal nesting beaches worldwide (Hirth, 1997; Nodarse et al., 2000; Peñaloza, 2000; Atkinson et al., 2011). However, the interval between successive nesting is difficult to determine because it was not possible to complete a full spatial and temporal sampling with the assurance that all returning females would have been counted. This parameter is difficult to consider in beach-like Aves Island, where the logistical circumstances and weather conditions, such as tropical storms and hurricanes, may interrupt or hinder the monitoring activities and the reproductive activity of turtles (Goldenberg, Landsea, Mestas-Nuñez, \& Gray, 2001; Hays et al., 2002; Vera \& Buitrago, 2012). The values observed in the 2010 season show intervals 
of 30 to 76 days without intermediate nesting, which could be influenced by the tropical storms and hurricanes (Earl, Fiona, Igor, Lisa, Otto, Matthew and Thomas) registered between August and October in the Caribbean (National Hurricane Center [NHC], 2010). On the other hand, the OCF and ECF Means during the season were lower than other values reported in the Atlantic for C. mydas (Hirth, 1997), but higher than those reported by Vera and Buitrago (2012) for the RFSIA population, which is possibly due to high number of females with one nest $(\mathrm{N}=576)$. In addition, the lack of correlation with the morphometrics of nesting females let us infer that clutch frequency is more influenced by factors such as turtle condition and health (Johnson \& Ehrhart, 1996; Broderick et al., 2003; Prieto-Torres et al., 2012; 2013).

Previous estimations of the number of nesting females on Aves Island are highly variable, especially regarding observation periods (days, weeks, months) and methods of calculation. Thus, few data were available in order to make comparisons with our results. These previous estimations include the use of a system to approximate the missing data in existing information for each nesting season, based upon a regression of the number of females that should have been observed during the period not sampled (Peñaloza, 2000; Jackson et al., 2008; Vera \& Buitrago, 2012). Previous studies estimated 300-500 females per season (Pritchard \& Trebbau, 1984; Guada \& Buitrago, 2008) and a population size of 347-1439 breeding females over the course of the 19 years of study from 1979 to 1997 (Peñaloza, 2000). Recently, Vera and Buitrago (2012) obtained for the 20012008 seasons an estimation of 373-1 669 nesting green turtle females in RFSIA. An evident trend exists in the increase in number of nesting females per season after the declaration in 1972 of Aves Island as a Wildlife Refuge and the installation of BCNASBO on the island for the monitoring and protection of the species.

In general, our study reinforces the importance of the RFSIA area for the green turtles nesting, where a consistent number of nesting females have visited during recent years (Vera \& Buitrago, 2012). The results presented in our study indicated that the number of nesting females continued to increase over the study period, which is constant with reports for other populations in the Caribbean, such as Tortuguero in Costa Rica (Atkinson, Berrondo \& Harrison, 2010; Atkinson et al., 2011), Cayo Largo Beach and Guanahacabibes Peninsula, both in Cuba (Nodarse et al., 2010, Aranza et al., 2013), which suggests a promising sign of this population recovering as result of longterm conservation efforts (Troëng \& Rankin, 2005; Vera \& Buitrago, 2012).

Our survey suggests RFSIA may support a larger number of green turtles than previously recorded, and this offshore island population is important to the survival of this species in the Caribbean. Aves Island Wildlife Refuge is considered today among the largest nesting colonies for green turtles in the Atlantic, including Tortuguero (Costa Rica) in the Caribbean (where about 22500 females nest each year), Ascension Island (3400 nesting females), and Trinidad Island in Brazil (3 000; Spotila, 2004). However, it is necessary to understand that a well-protected nesting beach not only attracts more female turtles to lay their clutches, but also ensures high hatchling success and their protection, and thus increases the reproductive success of the population (Miller, 1999; Seminoff, 2004).

Although nesting females can nest any day of the year in RFSIA (Vera \& Buitrago, 2012), reproductive activities during the 2010 season were concentrated in the months of August to October, and coincide with the most important nesting periods documented for the species in Atlantic (Aranza, Ibarra, Espinoza, Díaz, \& González-Sansón, 2003; Nodarse et al., 2010; Atkinson et al., 2010, 2011). However, interannual variability in the number of nesting activities observed, compared with previous years in RFSIA reported by Vera and Buitrago (2012), has been considered a result of the availability and quality of food (Broderick, Godley, \& Hays, 2001), as well as the climatic changes in the Atlantic region (Goldenberg et 
al., 2001) that affect the beginning of nesting in a season (Hawkes, Broderick, Godfrey, \& Godley, 2009). This means that alternate years may exist with either a high or low number of reproductive events on the same beach, confirming the need for long-term monitoring in order to describe population trends (Broderick et al., 2001; Vera \& Buitrago, 2012).

The spatial distribution of clutches showed a preference for the Northern areas of the beach, which has a larger area, lower water levels than the central section, and minimal incidence of artificial external light from BCNASBO (installed in 2004), which is located in the Southern section of the island. The clutch size and incubation period were consistent with populations documented in the Atlantic Ocean in other sites such as Cuba (Nodarse et al., 2000; Ferrer et al., 2007), Syria (Rees et al., 2005), and Costa Rica (Atkinson et al., 2010, 2011). We observed that the internesting and remigration periods did not necessarily indicate that females were physiologically prepared for reproduction, and that variances in these periods for ectothermic animals, such as sea turtles, are influenced by other ecological factors during the season as well solar radiation, cloud cover, and low temperatures (Godfrey \& Mrosovsky, 1997; Hirth, 1997; Hawkes et al., 2009).

We observed lower hatching and emergence values for green turtle nests in RFSIA in comparison with another indexed nesting beaches index, Tortuguero (Atkinson et al., 2010, 2011). We considered that the principal factors for lower observed values are the high density of nests and the flooding of nests during high rainfall due to tropical storms and hurricanes (NHC, 2010). This may influence levels of moisture and the compaction of sand, thus preventing the development of embryos and facilitating the proliferation of fungi, bacteria, as well as high numbers of eggs without apparent development and high mortality rates in clutches (McGhee, 1990; Dal Pont \& Krause, 2001). The results obtained for the 36 relocated nests suggested that clutches should preferably be maintained in situ due to the numerous environmental fluctuations that may affect the island during a season, including logistical circumstances in a high density nesting island, where the improper handling of eggs during transport and planting and interrupted the process of embryonic development (McGhee, 1990; Dal Pont \& Krause, 2001; Hawkes et al., 2009).

This study represents an integrative analysis of breeding biology for the nesting population of Chelonia mydas during the 2010 season in RFSIA, which included for first time a completed evaluation of spatial distribution and size, incubation period, hatching, and emergence success. Care should be taken in extrapolating our data to other years, as there is a need to continue monitoring the nesting beach and developing conservation strategies directed at all life-stages of the population. The loss of nests or constant low rates hatching and emergence can destroy a population in the long-term despite the lack of evidence in short-term effect (Seminoff, 2004). In a place as logistically difficult as Aves Island, these strategies requires a great effort that must be supported with appropriate and timely resources (Vera \& Buitrago, 2012), in order to annually obtain a database robust enough to display population dynamics in the long-term and contribute to an improvement in the status of the species populations in the Caribbean and Atlantic. Future researches to long-term in these and other reproductive parameters would increase our knowledge about the importance of RFSIA as a source rookery for coastal areas in Venezuela and Caribbean, as has been demonstrated in the Galapagos Islands (Seminoff et al., 2008).

\section{ACKNOWLEDGMENTS}

We would like to acknowledge the contributions of the following organizations and individuals. Financial support was provided by Universidad del Zulia. Venezuelan Ministry of Environment (Minamb) and the Venezuela Navy (DHN and BCNASBO) provided access to Aves Island Wildlife Refuge and support logistic (Minamb' License $\mathrm{N}^{\circ} 163$ ) while in 
the field. This manuscript was improved by comments from Jeffrey Seminoff, Fernando Rojas-Runjaic, Jesús Muñoz, Gustavo Aguirre and Mariana Fuentes. Daniela Prado, Giomara La Quay and Cristina Vallejo kindly reviewed the translation.

\section{RESUMEN}

Biología reproductiva y éxito de eclosión de la población de Chelonia mydas (Testudines: Cheloniidae) en el Refugio de Fauna Silvestre Isla de Aves, Venezuela, durante la temporada reproductiva 2010. El Refugio de Fauna Silvestre Isla de Aves (Venezuela) es la segunda colonia anidadora más importante para la tortuga verde (Chelonia mydas) en el Caribe, y su proyecto de investigación representa una sólida fuente de conocimiento sobre la ecología de esta especie. Sin embargo, existe poca información disponible sobre su biología reproductiva. Esta investigación estuvo enfocada en la evaluación de las características reproductivas y éxito de eclosión de la población anidadora durante la temporada 2010 en Isla de Aves. Los datos de anidación fueron recogidos a lo largo de la playa durante patrullajes nocturnos del 31 de julio al 09 de noviembre con el fin de determinar la actividad de anidación de las tortugas. Todas las hembras fueron marcadas y medidas para comparar los datos de las nuevas reclutas con los de las hembras remigrantes. Fue determinado el número de hembras anidadoras, el tamaño y la distribución espacial de las nidadas, el período de incubación, los períodos interanidación y remigración, así como el éxito de eclosión y emergencia por primera vez en la RFSIA. Se midieron las dimensiones de playa para determinar la densidad de nidos a lo largo de sus secciones. Fueron registradas 1106 hembras anidadoras, de las cuales 436 hembras fueron identificadas individualmente como remigrantes. Las hembras anidadoras tuvieron un largo curvo del caparazón promedio de $112.2 \pm 5.5 \mathrm{~cm}$. La media para el tamaño de las nidadas fue de $124.0 \pm 25.7$ huevos, con una frecuencia de puesta estimada de 2.0 nidos/hembra y un intervalo de puesta inferido de 12.4 días. Estimamos un total de $2261 \pm 33$ nidadas y un rango de $1130 \pm 17$ hembras anidadodra para la temporada 2010. Para las nidadas in situ observamos un éxito de eclosión de $54.4 \pm 30.0 \%$ y un éxito de emergencia de $74.3 \pm 29.2 \%$. Observamos una correlación positiva entre la morfometría de las hembras anidadoras y el tamaño de la nidada, así como diferencias significativas en el número de nidadas, los éxitos de eclosión y emergencia entre las tres secciones de la isla. Estos resultados son una primera aproximación para la caracterización de la población de Isla de Aves, pero tienen gran valor para establecer prioridades de conservación dentro del contexto de los planes de manejo nacionales. Los valores observados en este trabajo deben ser extrapolados con cuidados a otros años, ya que existe una importante necesidad de continuar con el monitoreo de la anidación, así como de desarrollar estrategias de conservación dirigidas a todas las etapas de vida de la población.

Palabras clave: Isla de Aves, Chelonia mydas, éxito de eclosión, población anidadora, éxito reproductivo.

\section{REFERENCES}

Alvarado, J. \& Murphy, T. M. (1999). Nesting Periodicity and Internesting Behavior. In K. L. Eckert, K. A. Bjorndal, F. A. Abreu-Grobois, \& M. Donnelly (Eds.), Research and Management Techniques for the Conservation of Sea Turtles (pp. 115-118). Washington D.C. USA: Marine Turtle Specialist Group. IUCN/SSC.

Aranza, J., Ibarra, M., Espinosa, G., Díaz, R., \& GonzálezSansón, G. (2003). Conducta de anidación de la tortuga verde (Chelonia mydas) en las playas Antonio y Caleta de los Piojos de la Península de Guanahacabibes, Pinar del Río, Cuba. Revista de Investigaciones Marinas, 24, 231-240.

Aranza, J., Ibarra, M., González, G., Abreu, F. A., Eckert, K., Espinosa, G., \& Omaya, K. (2013). Nesting ecology of Chelonia mydas (Testudines: Cheloniidae) on the Guanahacabibes Peninsula, Cuba. Revista de Biología Tropical, 61(4), 1935-1945.

Atkinson, C., Nolasco, D., \& Harrison, E. (2011). Reporte del Programa de Tortuga Verde 2010, Tortuguero, Costa Rica. Presentado a la Caribbean Conservation Corporation y al Ministerio de Ambiente y Energía de Costa Rica.

Atkinson, C., Berrondo, L., \& Harrison, E. (2010). Reporte del Programa Tortuga Verde 2009, Tortuguero, Costa Rica. Presentado a la Caribbean Conservation Corporation y al Ministerio de Ambiente y Energía de Costa Rica.

Bolten, A. (1999). Techniques for Measuring Sea Turtles. In K. L. Eckert, K. A. Bjorndal, F. A. Abreu-Grobois, \& M. Donnelly (Eds.), Research and Management Techniques for the Conservation of Sea Turtles (pp. 110-114). Washington D.C. USA: Marine Turtle Specialist Group. IUCN/SSC.

Broderick, A. C., Glen, F., Godley, B. J., \& Hays, G. C. (2003). Variation in reproductive output of marine turtles. Journal of Experimental Marine Biology and Ecology, 288, 95-109. doi:10.1016/ S0022-0981(03)00003-0

Broderick, A. C., Glen, F., Godley, B. J., \& Hays, G. C. (2002). Estimating the number of green and loggerhead turtles nesting annually in the Mediterranean. Oryx, 36(3), 227-236. doi: 10.1017/ S0030605302000431

Broderick, A. C., .Godley, B. J., \& Hays, G. C. (2001). Trophic status drives interannual variability in nesting 
numbers of marine turtles. Proceedings of the Royal Society of London Series B-Biological Sciences, 268, 1481-1487. doi: 10.1098/rspb.2001.1695

Dal Pont, M., \& Krause, L. (2001). As conseqüencias Do Manejo sobre os Ninhos de Dermochelys coriácea (Linneus, 1766), Junto ao Proyeto TAMAR-IBAMA, Espíritu Santo, Brasil. Cuadernos de Herpetología, 15(2), 97-106.

Eckert, K. L., Bjorndal, K. A., Abreu-Grobois, F. A., \& Donnelly, M. (2000). Técnicas de investigación y manejo para la conservación de las tortugas marinas. Washington D.C. USA: UICN/CSE Grupo Especialista en Tortugas Marinas. Publicación No. 4.

Ferrer, Y., Díaz, R., \& Díaz, F. R. (2007). Características de la anidación de la tortuga verde, Chelonia mydas (Testudinata, Cheloniidae), en la playa Caleta de los Piojos, Cuba, a partir de marcaciones externas. Animal Biodiversity and Conservation, 30(2), 211-218.

Gerrodette, T., \& Taylor, B. (1999). Estimating population size. In K. L. Eckert, K. A. Bjorndal, F. A. Abreu-Grobois, \& M. Donnelly (Eds.), Research and Management Techniques for the Conservation of Sea Turtles (pp. 67-71). Washington D.C., U.S.A.: Marine Turtle Specialist Group. IUCN/SSC.

Godfrey, M. H., \& Mrosovsky, N. (1997). Estimating the time between hatching of sea turtles and their emergence from the nest. Chelonian Conservation and Biology, 2, 581-585.

Goldenberg, S., Landsea, C., Mestas-Nuñez, A., \& Gray, W. (2001). The Recent Increase in Atlantic Hurricane Activity: Causes and Implications. Science, 293, 474479. doi: $10.1126 /$ science. 1060040

Gremone, C. \& Gómez, J. (1983). Isla de Aves como área de desove de la tortuga verde Chelonia mydas: Biología Reproductiva y Morfometría con Observaciones Adicionales Sobre El Ecosistema y Las Aves 19791983. Caracas, Venezuela: Fundación para la Defensa de la Naturaleza (FUDENA).

Guada, H. J., \& Solé, G. S. (2000). Plan de Acción para la Recuperación de las Tortugas Marinas de Venezuela (Informe Técnico del PAC No. 39 edition). Kingston, Jamaica: UNEP Caribean Environment Programme.

Guada, H. J. \& Buitrago, J. (2008). Tortuga verde. In J. P. Rodríguez, \& F. Rojas-Suárez (Eds.), Libro Rojo de la Fauna Venezolana (pp. 169). Caracas, Venezuela: Provita y Shell Venezuela, S.A.

Hawkes, L., Broderick, A., Godfrey, M., \& Godley, B. (2009). Climate change and marine turtles. Endangered Species Research, 7, 137-154. doi: 10.3354/ esr00198

Hays, G. C., Broderick, A. C., Glen, F., Godley, B. J., Houghton, J. D. R., \& Metcalfe, J. D. (2002). Water temperature and internesting intervals for loggerhead
(Caretta caretta) and green (Chelonia mydas) sea turtles. Journal of Thermal Biology, 27, 429-432.

Hirth, H. F. (1997). Synopsis of Biological Data on the Green turtle, Chelonia mydas (Biological Report 97). U.S. Fish and Wildlife Service. U.S. Department of the Interior.

Huerta, P. (1998). Fotoidentifiación: Un método alternativo de Marcaje de Tortugas Laúd, Dermochelys coriacea (Trabajo de Grado). Universidad Autónoma de México, México.

Jackson, A. L., Broderick, A. C., Fullerb, W. J., Glen, F., Ruxtond, G. D., \& Godley, B. (2008). Sampling design and its effect on population monitoring: How much monitoring do turtles really need? Biological Conservation, 141(12), 2932-2941. doi:10.1016 /j.biocon. 2008.09.002

Johnson, S., \& Ehrhart, L. (1996). Reproductive Ecology of the Florida Green Turtle: Clutch Frequency. Journal of Herpetology, 30, 407-410.

McGhee, M. (1990). Effects of moisture on eggs and hatchling of Loggerhead Sea Turtle (Ceretta caretta). Herpetology, 46, 251-258.

Miller, J. D. (1997). Reproduction in sea turtles. In P. L. Lutz, \& J. A. Musik (Eds.), The Biology of the Sea Turtles (pp. 51-80). Boca Ratón, FL. USA: CRC Press.

Miller, J. D. (1999). Determining Clutch Size and Hatching Success. In K. L. Eckert, K. A. Bjorndal, F. A. Abreu-Grobois, \& M. Donnelly (Eds.), Research and Management Techniques for the Conservation of Sea Turtles (pp. 124-129). Washington D.C. USA: Marine Turtle Specialist Group. IUCN/SSC.

National Hurricane Center (NHC). (2010). Atlantic Hurricane Season. Retrived from http://www.nhc.noaa.gov /2010atlan.shtml.

Nodarse, G., Moncada, F., Meneses, A., \& Rodríguez, C. (2000). Long-term monitoring of nesting of the Green Sea Turtle (Chelonia mydas) in the southwest platform of Cuba. In F. A. Abreu-Grobois, R. Briseño-Dueñas, R. Márquez, \& L. Sarti-Martínez (Eds.), Proceedings of the Eighteenth Annual Symposium on Sea Turtle Biology and Conservation (pp. 68-69). Miami FL. USA: NOAA Technical Memorando. NMFS-SEFSC- 436.

Nodarse, G., Moncada, F., Medina, Y., Rodríguez, C., Hernández, F., Blanco, B., \& Escobar, E. (2010). Comportamiento de la anidación de tortugas marinas en los Cayos San Felipe y Archipiélago de los Canarreos, Cuba (2001-2006). Revista Cubana de Investigaciones Pesqueras, 27, 67-72.

Peñaloza, C. (2000). Demografía y viabilidad de la población de tortuga verde, Chelonia mydas, en Isla de Aves (Trabajo Especial de Grado). Universidad Central de Venezuela, Venezuela. 
Piedra, R., Vélez, E., Dutton, P., Possardt, E., \& Padilla, C. (2007). Nesting of the Leatherback turtle (Dermochelys coriacea) from 1999-2000 through 2003-2004 at Playa Langosta, Parque Nacional Marino Las Baulas de Guanacaste, Costa Rica. Chelonia Conservation and Biology, 6(1), 111-116.

Prieto-Torres, D., \& Hernández, J. (2014). Marcas por mordidas de tiburón y alteraciones morfologicas en hembras de tortuga verde (Chelonia mydas) presentes en el Refugio de Fauna Silvestre Isla de Aves, Venezuela. CIENCIA, 22(2), 73-79.

Prieto-Torres, D., Hernández, J., Bravo, A., Alvarado, M. C., \& Dávila, M. (2013). Blood Biochemistry of the Breeding Population of Green Turtles (Chelonia mydas) in the Aves Island Wildlife Refuge, Venezuela. South American Journal of Herpetology, 8 (3), 147-154. doi: http://dx.doi.org/10.2994/ SAJH-D-13-00010.1

Prieto-Torres, D., Hernández, J., Bravo, A., Alvarado, M. C., Dávila, M., \& Quiroz, N. (2012). Valores hematologicos de la población anidadora de tortuga verde (Chelonia mydas) en el Refugio de Fauna Silvestre Isla de Aves, Venezuela. Revista Científica FCV-LUZ, XXII, 273-280.

Pritchard, P. C. H., \& Trebbau, P. (1984). The turtle of Venezuela. Oxford Ohio USA: Society for study of amphibians and Reptiles, Contributions to Herpeto$\operatorname{logy}$ No 2 .

Rainey, W. E., \& Pritchard, P. C. H. (1972). Distribution and management of Caribbean sea turtles. St. Thomas US Virgin Islands: Virgin Islands Ecological Research Station, Caribbean Research Institute, College of Virgin Islands. Contribution No. 105.

Rainey, W. E. (1977). Tagging at Aves Island, Venezuela. Marine Turtle Newsletter, 2, 6-7.

Rees, A., Saad, A., \& Jony, M. (2005). Clutch size and hatching success of green turtle nests in Syria during 2004. In A. Demetropoulos, \& O. Turkozan (Eds.), Proceedings of the Second Mediterranean Conference on Marine Turtles (pp. 158-161). Kemer, Turkey: Barcelona Convention - Bern Convention - Bonn Convention (CMS).

Sarti, L., Barragán, A. R., García-Muñoz, D., García, N., Huerta, P., \& Vargas, F. (2007). Conservation and
Biology of the Leatherback Turtle in the Mexican Pacific. Chelonia Conservation and Biology, 6(1), 70-78.

Seminoff, J. A. (2004). Marine Turtle Specialist Group Review 2004 Global Status Assessment Green turtle (Chelonia mydas). Marine Turtle Specialist Group. The World Conservation Union (IUCN). Species Survival Comisión. Red List Programme. Washington, U.S.A.

Seminoff, J. A., Zárate, P., Coyne, M., Foley, D. G., Parker, D., Lyon, B. N., \& Dutton, P. H. (2008). Post-nesting migrations of Galápagos green turtles Chelonia mydas in relation to oceanographic conditions: Integrating satellite telemetry with remotely sensed ocean data. Endangered Species Research, 4, 57-72. doi: 10.3354/esr00066

Sims, M., Bjorkland, R., Mason, P., \& Crowder, L. B. (2008). Statistical power and sea turtle nesting beach surveys: How long and when? Biological Conservation, 141, 2921-2931. doi:10.1016/j. biocon.2008.07.021

Spotila, J. R. (2004). Sea turtles: A complete guide to their biology, behavior, and conservation. Baltimore, MD: Johns Hopkins University Press.

Tröeng, S. \& Rankin, E. (2005). Long-term conservation efforts contribute to positive green turtle, Chelonia mydas, nesting trend at Tortuguero, Costa Rica. Biological Conservation, 121(1), 111-116. doi:10.1016/j. biocon.2004.04.014

Vera, V. (2004). Proyecto de seguimiento y conservación de la población de tortuga verde (Chelonia mydas) en el Refugio de Fauna Silvestre Isla de Aves (Dependencia Federales). In R. Babarro, A. Sanz, \& B. Mora (Eds.). Tortugas marinas en Venezuela. Acciones para su conservación (pp. 55-61). Caracas, Venezuela: Oficina Nacional de Diversidad Biológica, Fondo Editorial Fundambiente.

Vera, V., \& Buitrago, J. (2012). Actividad reproductiva de Chelonia mydas (Testudines: Cheloniidae) en Isla de Aves, Venezuela (2001-2008). Revista de Biología Tropical, 60(2), 745-758. 